ARTICLE

\title{
Ru(II)Porphyrinate-based molecular nanoreactor for carbene insertion reactions and quantitative formation of rotaxanes by active-metal-template syntheses
}

Liniquer A. Fontana1, Marlon P. Almeida (10 1, Arthur F. P. Alcântara1,2, Vitor H. Rigolin', Marcos A. Ribeiro³, Wdeson P. Barros (10 ${ }^{1} \&$ Jackson D. Megiatto Jr. (1) ${ }^{1 凶}$

Selectivity in $\mathrm{N}-\mathrm{H}$ and $\mathrm{S}-\mathrm{H}$ carbene insertion reactions promoted by $\mathrm{Ru}(\mathrm{II})$ porphyrinates currently requires slow addition of the diazo precursor and large excess of the primary amine and thiol substrates in the reaction medium. Such conditions are necessary to avoid the undesirable carbene coupling and/or multiple carbene insertions. Here, the authors demonstrate that the synergy between the steric shielding provided by a Ru(II)porphyrinatebased macrocycle with a relatively small central cavity and the kinetic stabilization of otherwise labile coordinative bonds, warranted by formation of the mechanical bond, enables single carbene insertions to occur with quantitative efficiency and perfect selectivity even in the presence of a large excess of the diazo precursor and stoichiometric amounts of the primary amine and thiol substrates. As the Ru(II)porphyrinate-based macrocycle bears a confining nanospace and alters the product distribution of the carbene insertion reactions when compared to that of its acyclic version, the former therefore functions as a nanoreactor.

\footnotetext{
${ }^{1}$ Institute of Chemistry, University of Campinas (UNICAMP), POBox 6154, 13083-970 Campinas, Brazil. ${ }^{2}$ Instituto Federal do Sertão Pernambucano, Estrada do Tamboril, 56200-000 Ouricuri, Brazil. ${ }^{3}$ Departamento de Química, Universidade Federal do Espírito Santo, Av. Fernando Ferrari, 514, $29075-910$ Vitória, Brazil. ${ }^{凶}$ email: jdmj@unicamp.br
} 
$\mathrm{T}$ he rich coordination chemistry of porphyrinates ${ }^{1-18}$ is useful in the design of macrocyclic receptors, in which the porphyrinate subunits are positioned on the top of molecular capsules to create hollow structures with well-defined cavities ${ }^{19-28}$. In such molecular architectures, one of the axial positions of the metallic center is shielded from the environment, while the other has unencumbered reactivity. This asymmetry between the two axial coordination sites of the porphyrinate subunit can be explored to introduce a steric bias in the binding modes of the receptor ${ }^{18-22}$. For example, the porphyrinate's external axial position can be blocked by selective coordination of bulky and inert monodentate ligands. With such configuration of the ligands around the metal center, the internal coordination site of the porphyrinate-based receptor can bind nonbulky substrates to efficiently and selectively promote their reactions inside the central cavity ${ }^{23-32}$. Such versatile strategy has been explored in the active-metal template synthesis of interlocked molecules ${ }^{24-27}$, asymmetric catalysis ${ }^{28,29}$ and biomimetics ${ }^{30-32}$. However, in those applications, the porphyrinate-based macrocycles has virtually the same reactivity as their acyclic analogues.

To expand the scope of porphyrinate-based molecular capsules, incorporation of nanoreactor concepts ${ }^{33}$ are highly desirable. Nanoreactors are designed to create nanoscale chemical environments partitioned from the bulk in order to change the reactivity of molecules upon binding inside the cavity, therefore altering their behavior in chemical transformations. Congruently, nanoreactors can dramatically change the outcome of chemical reactions 33 .

The carbene transfer/insertion reactions promoted by $\mathrm{Ru}(\mathrm{II})$ porphyrinates from diazo derivatives are versatile synthetic methods as they catalyze a wide range of chemical transformations such as cyclopropanation, 1,3-dipolar cycloadditions, $\mathrm{X}-\mathrm{H}$ $(\mathrm{X}=\mathrm{C}, \mathrm{N}, \mathrm{O}$, and $\mathrm{S})$ insertions and olefination of aldehydes in the presence of phosphines ${ }^{34-42}$. However, the methodologies based on carbene transfer/insertion processes promoted by $\mathrm{Ru}(\mathrm{II})$ porphyrinates suffer from a serious drawback, which is the concurrent dimerization side-reaction of the carbene intermediates. To avoid the undesirable dimerization process, the methods described in the literature require slow addition of the diazo derivative into the reaction medium in order to keep the carbene concentration at low levels ${ }^{34-42}$. Such strategy has had limited success ${ }^{42}$, often requiring long addition times of the diazo derivative. Among the $\mathrm{X}-\mathrm{H}$ bond carbene insertion reactions, the $\mathrm{N}-\mathrm{H}$ one is problematic ${ }^{40-42}$ for two reasons. Firstly, competition between the primary amine and the diazo groups on the substrates for the $\mathrm{Ru}(\mathrm{II})$ porphyrinate axial coordination sites slows down or even shuts down the $\mathrm{Ru}(\mathrm{II})$ porphyrinate capability to generate carbene intermediates. Secondly, selectivity to the secondary amine product is hard to achieve and requires careful control of the diazo concentration and reaction temperature as well as to use a large excess of the amine substrate (10× relative to the diazo derivative) $)^{42}$ to avoid double carbenoid insertions that lead to the tertiary amine analog.

Herein, it is reported the molecular design and coordinative properties of a $\mathrm{Ru}(\mathrm{II})$ porphyrinate-based molecular capsule that works as a nanoreactor. The molecular capsule quantitatively yields an asymmetrical [2] rotaxanes through the challenging single $\mathrm{N}-\mathrm{H}$ carbenoid insertion by the active metal template technique using an equimolar mixture of substrates. No signs of dimerization side processes nor double insertions are observed in the rotaxane assembly reaction, even under severe experimental conditions for carbene transfer/insertion reactions $s^{34-42}$. Most surprisingly, the excess of substrates added to the reaction medium is completely recovered as unreacted materials after workup. That efficiency in formation of mechanical bonds is hard to achieve in the present case as the $\mathrm{Ru}(\mathrm{II})$ porphyrinate subunit on the macrocycle is still active after the rotaxane assembly process. Therefore, it was expected that intercomponent side reactions would plague our methodology as the inherent effective molarity effects of the mechanical bond should have favored such side reactions ${ }^{32}$. Conversely, the acyclic $\mathrm{Ru}(\mathrm{II})$ porphyrinate analog yields a product mixture composed of the carbene dimer and the mono/double inserted threads, highlighting the distinct reaction outcomes afforded by the two $\mathrm{Ru}(\mathrm{II})$ porphyrinates under the same conditions. A detailed structural investigation of the $\mathrm{Ru}(\mathrm{II})$ porphyrinate macrocyclic complex and the resulting [2] rotaxanes reveals the basic steps in which the macrocyclic $\mathrm{Ru}(\mathrm{II})$ porphyrinate operates to achieve the striking single $\mathrm{N}-\mathrm{H}$ bond carbene insertion selectivity. To demonstrate the synthetic generality of the present methodology, we also describe the quantitative active metal template synthesis of the parent thioether-containing rotaxane, which is assembled through the $\mathrm{S}-\mathrm{H}$ carbene insertion reaction. The findings reported herein demonstrate how the steric features of porphyrinate molecular capsules in combination with formation of mechanical bonds can be explored to change the reaction outcomes of challenging chemical transformations; the fundamental principle of nanoreactors.

\section{Results}

Molecular design and synthesis of the macrocyclic porphyrinbased ligand. The molecular design of the macrocyclic receptor 7 (Fig. 1) contemplates the structural requirements for the successful exploration of carbene insertion reactions. The molecular backbone of macrocycle 7 is exclusively composed of aromatic $\mathrm{C}-\mathrm{H}$ bonds, which are chemically inert to $\mathrm{Ru}(\mathrm{II})$-carbenoids ${ }^{34-42}$. The rigid aromatic backbone inevitably leads to formation of a well-defined and relatively small central cavity in 7 . The crystal structure (CCDC ID 1883084) of 7 (Fig. 2) reveals a virtually flat porphyrin core which together with the aromatic backbone creates a central cavity with dimensions of 8.49 and $7.91 \AA$ (centroidto-centroid of the phenyl spacers and porphyrin centroid-tomidpoint of $\mathrm{C} 26-\mathrm{C} 26^{\mathrm{i}}$ bond on the phenanthrene moiety, respectively, with symmetry code: $i=1 / 2-\mathrm{x}, \mathrm{y}, \mathrm{z}$; see

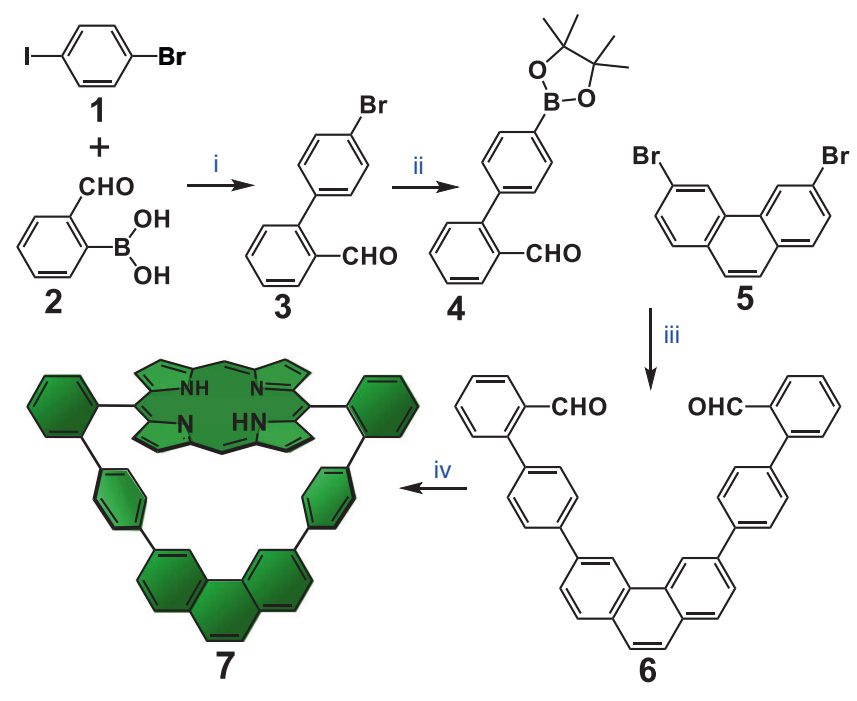

Fig. 1 Synthetic strategy for the preparation of macrocycle 7. Reagents and conditions: (i) $\mathrm{Pd}\left(\mathrm{PPh}_{3}\right)_{4}, \mathrm{Na}_{2} \mathrm{CO}_{3(\mathrm{aq})}, \mathrm{MePh} / \mathrm{EtOH}$, reflux, $16 \mathrm{~h}, \mathrm{~N}_{2}$ atmosphere, $80 \%$ yield; (ii) $\mathrm{Pd}(\mathrm{Cl})_{2} \mathrm{dppf}, \mathrm{B}_{2} \mathrm{pin}_{2}$, 1,4-dioxane, reflux, $16 \mathrm{~h}$, $\mathrm{N}_{2}$ atmosphere, 85\% yield; (iii) $\mathrm{Pd}\left(\mathrm{PPh}_{3}\right)_{4}, \mathrm{Na}_{2} \mathrm{CO}_{3 \text { (aq) }}, \mathrm{PPh}_{3}, \mathrm{MePh} /$ $\mathrm{MeOH}$, reflux, $48 \mathrm{~h}, \mathrm{~N}_{2}$ atmosphere, 95\% yield; (iv) dipyrromethane, TFA, $\mathrm{CH}_{2} \mathrm{Cl}_{2} / \mathrm{CHCl}_{3}(3: 1, \mathrm{v} / \mathrm{v})$, high dilution $(0.213 \mathrm{mM})$, rt, $20 \mathrm{~h}$, followed by $\mathrm{DDQ}, \mathrm{CH}_{2} \mathrm{Cl}_{2}$, reflux, $2 \mathrm{~h}, 20 \%$ yield. Macrocycle $\mathbf{7}$ is prepared in $13 \%$ total yield relative to 2 . 

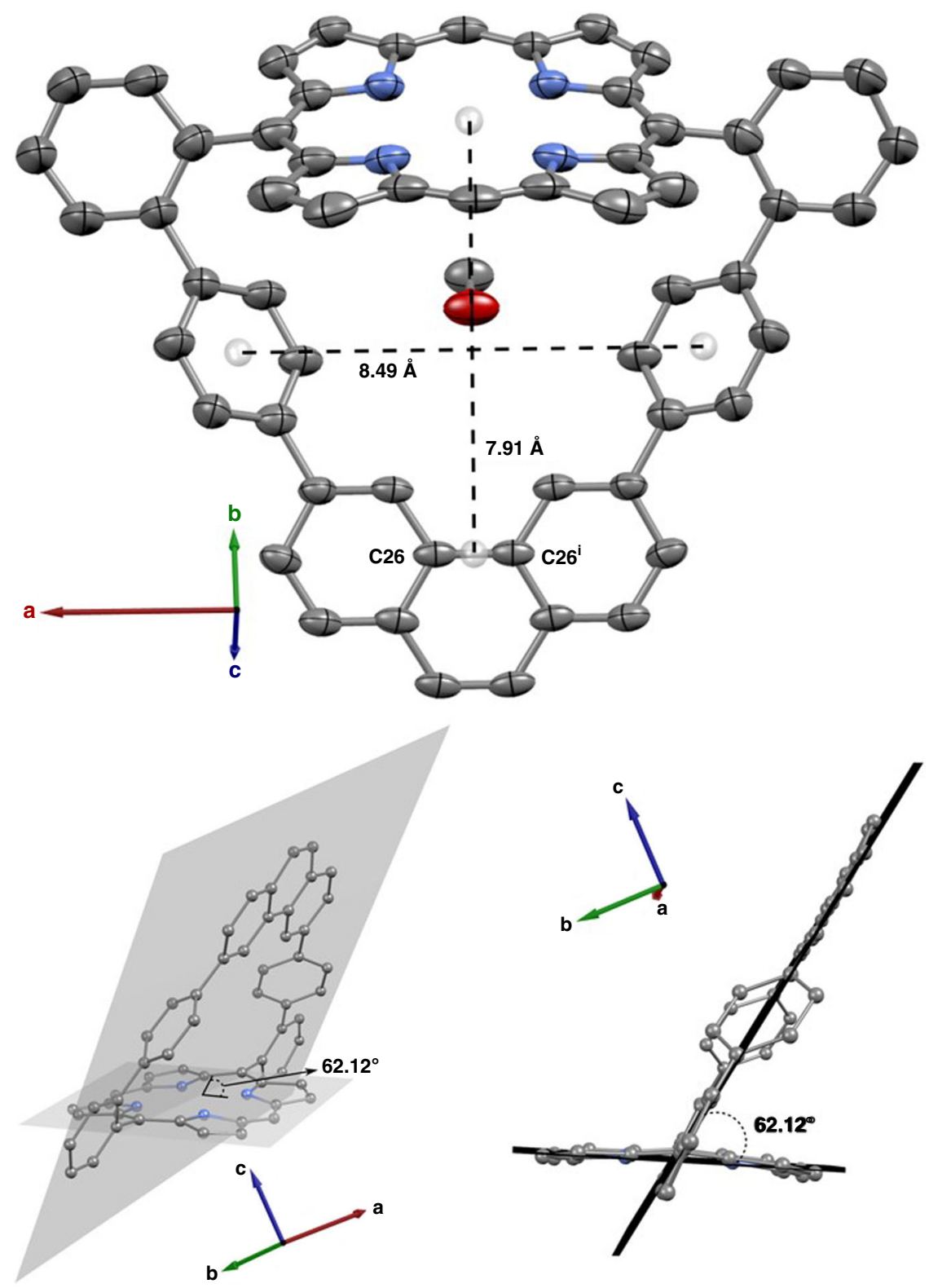

Fig. 2 Representation of the crystal structure of macrocycle 7. Single crystals were grown from a dichloromethane/methanol/tetrahydrofuran saturated solution by slow evaporation. Carbon atoms are shown in gray, nitrogen in blue and oxygen in red. Hydrogen atoms are omitted for clarity purposes. Ellipsoids are drawn at 50\% probability levels. Symmetry code: $i=1 / 2-x, y, z$. See Supplementary Fig. S1 for complete atom numbering. CCDC ID 1883084.

Supplementary Fig. S1 for complete atom numbering). Such cavity dimensions in 7 are rather smaller than those observed for a similar but semi-rigid porphyrin-based macrocycle reported in our previous works ${ }^{24,25}$ (cavity dimensions 10.30 and $8.40 \AA$ ).

The angle between the porphyrin and the molecular aromatic loop mean planes is $62.12^{\circ}$, which is smaller than the expected $90^{\circ}$. Although that indicates that the molecular loop and porphyrin mean planes are not orthogonal in the solid state, NMR investigation informs that the meso-aryl rings are rapidly oscillating through their perpendicular orientation to the porphyrin mean plane ${ }^{43}$, which in turn allow the phenanthrene moiety to rapidly swing back-and-forth below the porphyrin centroid in solution. Such fast swinging movement renders the two faces of macrocycle 7 magnetically equivalent. Accordingly, all resonances are sharp and distinct in the ${ }^{1} \mathrm{H}$ NMR spectrum of 7 (Supplementary Fig. S2), thus confirming the proposed hollow structure in solution (see Supplementary material for further discussion).
Structural and coordinative properties of the macrocyclic Ru (II)porphyrinate complexes. With the structural requirements for a porphyrin-based macrocyclic ligand satisfied by 7 , we turned our attention to prepare the corresponding $\mathrm{Ru}(\mathrm{II})$ porphyrinate using the classical metalation protocol with $\mathrm{Ru}_{3}(\mathrm{CO})_{12}$ as the metal source followed by purification in the presence of methanol $^{36}$. In principle, metalation of macrocycle 7 under those conditions should have afforded a mixture composed of $\mathrm{Ru}(\mathrm{II})$ porphyrinate 8 and its isomer 9 (Fig. 3) as the central cavity provides no steric shielding for the selective coordination of small axial ligands such as carbonyl and methanol molecules. However, only one porphyrin product is isolated from the crude mixture. The ${ }^{1} \mathrm{H}$ NMR spectrum of the isolated product is not consistent with the proposed isomeric mixture and reveals the expected set of signals for a single $\mathrm{Ru}(\mathrm{II})$ porphyrinate-based macrocycle (Supplementary Fig. S3) ${ }^{35}$. Congruently, ${ }^{13} \mathrm{C}$ NMR and FTIRATR analyses (Supplementary Figs. S4 and S5, respectively) show one single resonance at $\delta=180.1 \mathrm{ppm}$ and one stretching band 


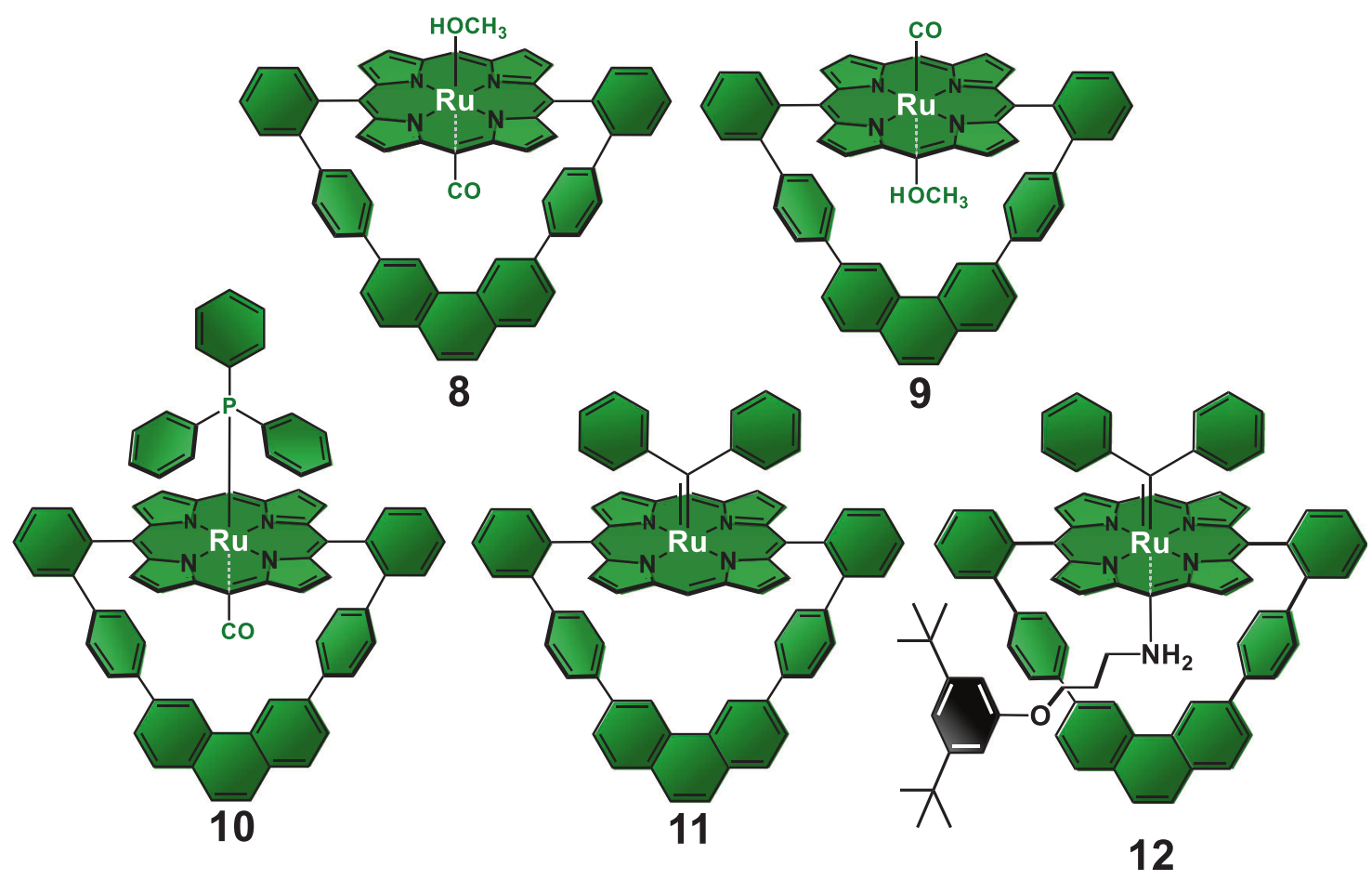

Fig. 3 Molecular structures of the Ru(II)porphyrinate complexes. Complex 9 is not observed in our experiments.

$\left(v_{\mathrm{CO}_{\text {strect }}}=1926 \mathrm{~cm}^{-1}\right)$ for the carbonyl axial ligand in the isolated product, thus confirming formation of one single complex. Such coordinative properties are not ubiquitous as performing the metalation reaction under the same conditions used for 7 but with our previously reported ${ }^{24,25}$ semi-rigid and larger macrocycle as ligand yields the two expected isomers as revealed by ${ }^{1} \mathrm{H}$ NMR spectroscopy (for spectrum and chemical structures, see Supplementary Fig. S6). Therefore, the structural features of 7 , which yield a hollow receptor with a relatively small central cavity, is most likely the reason for such selectivity in the metalation reaction.

To identify which isomer, $\mathbf{8}$ or $\mathbf{9}$, is isolated from the metalation reaction of macrocycle 7 , we took advantage of the steric constraints imposed by the central cavity in $\mathbf{8}$ and $\mathbf{9}$, along with the high affinity of $\mathrm{Ru}(\mathrm{II})$ ions for phosphorus-based ligands and the ring current effects provided by the porphyrin subunit. We reasoned that bulky triphenylphosphine species $\left(\mathrm{PPh}_{3}\right)$ would easily displace the loosely bound and labile methanol axial ligand but not the kinetically robust carbonyl one in the coordination sphere of the $\mathrm{Ru}(\mathrm{II})$ ions in both isomers ${ }^{44}$. However, the internal axial position in isomer 9 would not be available for the incoming bulky $\mathrm{PPh}_{3}$ ligand due to the steric shielding provided by the appended aromatic loop. Conversely, the external position in complex 8 would be unencumbered, thereby allowing the substitution of the $\mathrm{PPh}_{3}$ ligand for the methanol one. If such ligand substitution reaction takes place, the ring current effects provided by the porphyrin core would shield the protons of the phenyl groups in the $\mathrm{PPh}_{3}$ ligand in the ${ }^{1} \mathrm{H}$ NMR spectrum of the product. Therefore, the shielding of the $\mathrm{PPh}_{3}$ protons is a probe for the identification of the isolated product as complex $\mathbf{8}$ or $\mathbf{9}$ by ${ }^{1} \mathrm{H}$ NMR spectroscopy.

Treatment of the unidentified $\mathrm{Ru}(\mathrm{II})$ porphyrinate with excess of $\mathrm{PPh}_{3}$ in dichloromethane at room temperature followed by precipitation of the crude with petroleum ether lead to the axial ligand substitution reaction to quantitatively yield complex $\mathbf{1 0}$ (Fig. 3). ${ }^{1} \mathrm{H}$ NMR analysis (Supplementary Fig. S7) clearly reveals the strong shielding of the protons of the $\mathrm{PPh}_{3}$ axial ligand, hence giving unmistakable evidence for the exclusive formation of $\mathbf{1 0 .}$.

For our purposes, complex $\mathbf{8}$ is useless as the stable and inert axial carbonyl ligand is coordinated to the $\mathrm{Ru}(\mathrm{II})$ ion inside the macrocycle's cavity. Therefore, we investigated several protocols to substitute the internal carbonyl axial ligand in $\mathbf{8}$ with other ligands. Thermolysis ${ }^{44}$, photolysis ${ }^{45}$, and chemical oxidative decarbonylation reactions ${ }^{46}$ all failed in our hands, suggesting that the cavity provide the carbonyl ligand with great stability. Gratefully, treating 8 with diphenyldiazomethane ${ }^{34}$ in dichloromethane at room temperature followed by purification by column chromatography on neutral alumina affords target complex 11 (Fig. 3).

The proposed molecular structure of complex $\mathbf{1 1}$ is confirmed by $\mathrm{x}$-ray diffraction on single crystals grown from slow evaporation of a dichloromethane/acetonitrile saturated solution of 11 (Fig. 4, CCDC ID 1988009). The organic backbone of the complex is virtually identical to that of the free ligand macrocycle 7 (Fig. 2), including the cavity dimensions. The complex has a distorted octahedral symmetry with a residual water molecule bound to the internal axial position and with the $\mathrm{Ru}(\mathrm{II})$ ion displaced 0.1449(8) $\AA$ from the porphyrin mean plane toward the carbene ligand. The axial $\mathrm{Ru}-\mathrm{C}$ bond distance in 11 is 1.852(4) $\AA$ and thus comparable to those reported for other similar carbene$\mathrm{Ru}(\mathrm{II})$ porphyrinates $(1.841-1.876 \AA)^{38}$. However, the $\mathrm{Ru}-\mathrm{C}$ bond distance in $\mathbf{1 1}$ is significantly shorter when compared to the single $\mathrm{Ru}-\mathrm{C}$ bonds $(1.978-2.088 \AA)^{42,47}$ usually observed in ruthenium complexes with $\mathrm{N}$-heterocyclic carbene ligands. The short $\mathrm{Ru}-\mathrm{C}$ bond distance together with the displacement of the $\mathrm{Ru}(\mathrm{II})$ ion from the porphyrin mean plane towards the carbene ligand reveals the formation of a robust axial $\mathrm{Ru}-\mathrm{C}$ coordinative interaction with partial double bond character in $\mathbf{1 1}^{48}$. Accordingly, the carbene carbon atom receives non-negligible electronic density back from the Ru ion ( $\pi$-back donation $)^{48,49} .{ }^{1} \mathrm{H}$ NMR analysis on $\mathbf{1 1}$ confirms that the solid-state structural features are preserved in solution. The well-defined and sharp signals observed in the ${ }^{1} \mathrm{H}$ NMR spectrum of 11 (Fig. 5, top) inform 

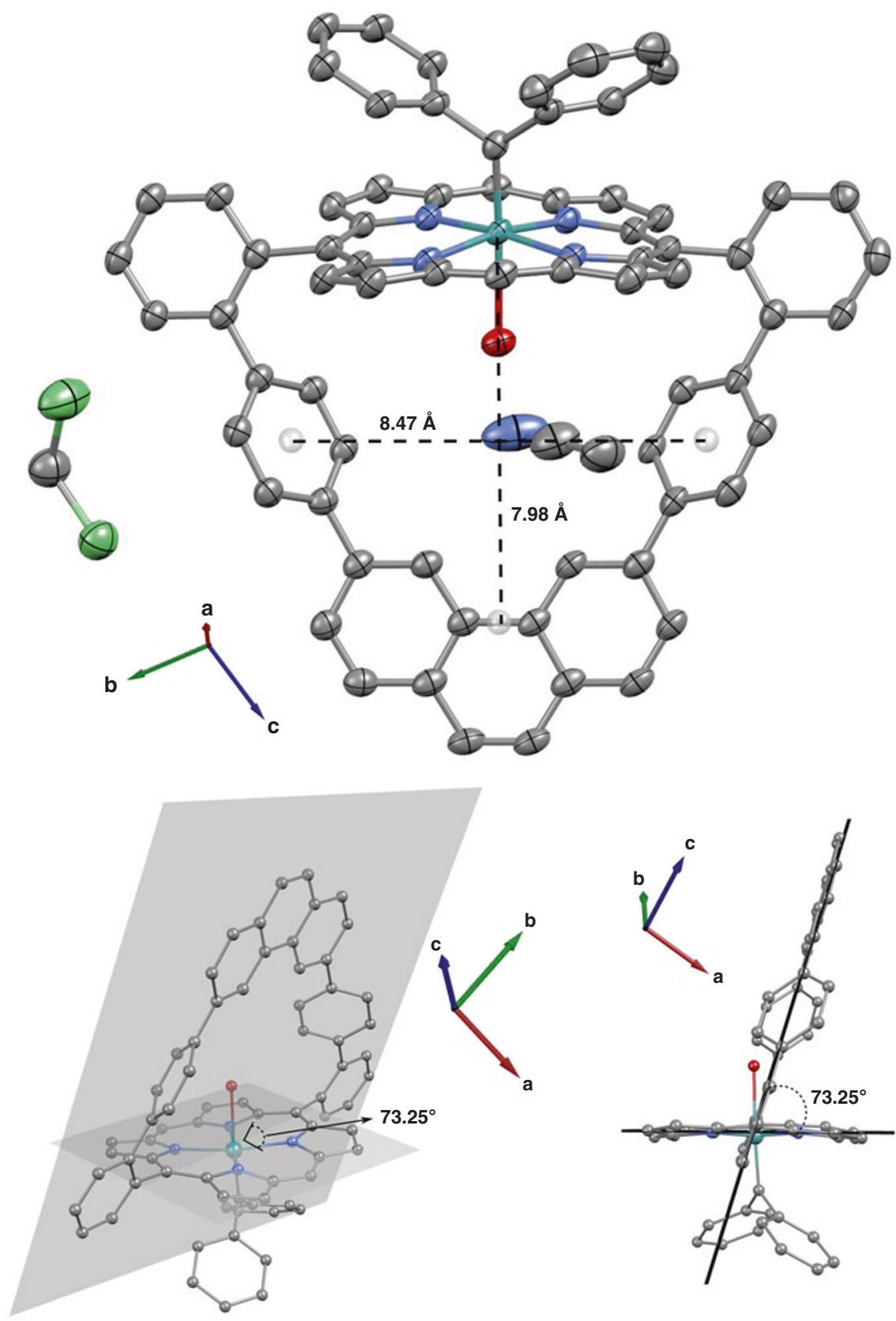

Fig. 4 Representation of the crystal structure of macrocycle 11. Single crystals were grown from a dichloromethane/acetonitrile saturated solution by slow evaporation. Carbon atoms are shown in gray, nitrogen in blue, oxygen in red, ruthenium in turquoise and chlorine in green. Hydrogen atoms are omitted for clarity purposes. Ellipsoids are drawn at 50\% probability levels. CCDC ID 1988009.

that the axial carbenoid ligand is inert in solution, which is also a consequence of the strong $\mathrm{Ru}-\mathrm{C}$ axial bond. Such electronic interactions provide $\mathbf{1 1}$ with great thermal and chemical stability ${ }^{47-49}$, which in conjunction with the inertness of the carbenoid ligand in solution, yield the structural features required for an excellent endotopic promoter.

Active-metal-template syntheses of asymmetrical [2]rotaxanes through carbene insertion reactions and the nanoreactor effect. To demonstrate the endotopic properties of complex 11, we developed an active-metal template synthesis ${ }^{50,51}$ of an asymmetrical [2] rotaxanes through the problematic $\mathrm{N}-\mathrm{H}$ carbene insertions (Fig. 6a) ${ }^{40,41}$ under relatively severe experimental conditions. Accordingly, we decided to add in one portion a relatively large excess of half-threads 13 and 14 (10 equiv) relative to macrocycle 11 ( 1 equiv). After 3 hours at room temperature, no reaction was observed. That inactivity is due to the coordination of the amino group in $\mathbf{1 3}$ to the internal axial position of the $\mathrm{Ru}(\mathrm{II})$ ion in $\mathbf{1 1}$ to form hexacoordinated complex $\mathbf{1 2}$ (Fig. 3), whose structure is unambiguously confirmed by comparing the ${ }^{1} \mathrm{H}$ NMR spectra of complex 12, macrocycle 11 and half-thread 13 (see Supplementary Fig. S8 for spectra and further discussion).

The $\mathrm{RH}_{2} \mathrm{~N}-\mathrm{Ru}$ coordinative bond in $\mathbf{1 2}$ is inert at room temperature and shuts down the $\alpha$-estercarbenoid production by 11 from diazo half-thread $\mathbf{1 4}^{34-42}$. However, the interaction becomes labile at higher temperatures as heating the reaction mixture at $60{ }^{\circ} \mathrm{C}$ results in smooth and total interlocking of macrocycle 11. Significantly, the excess of half-threads 13 and 14 added to the reaction medium is completely recovered as unreacted materials after purification of the crude. No signs of 

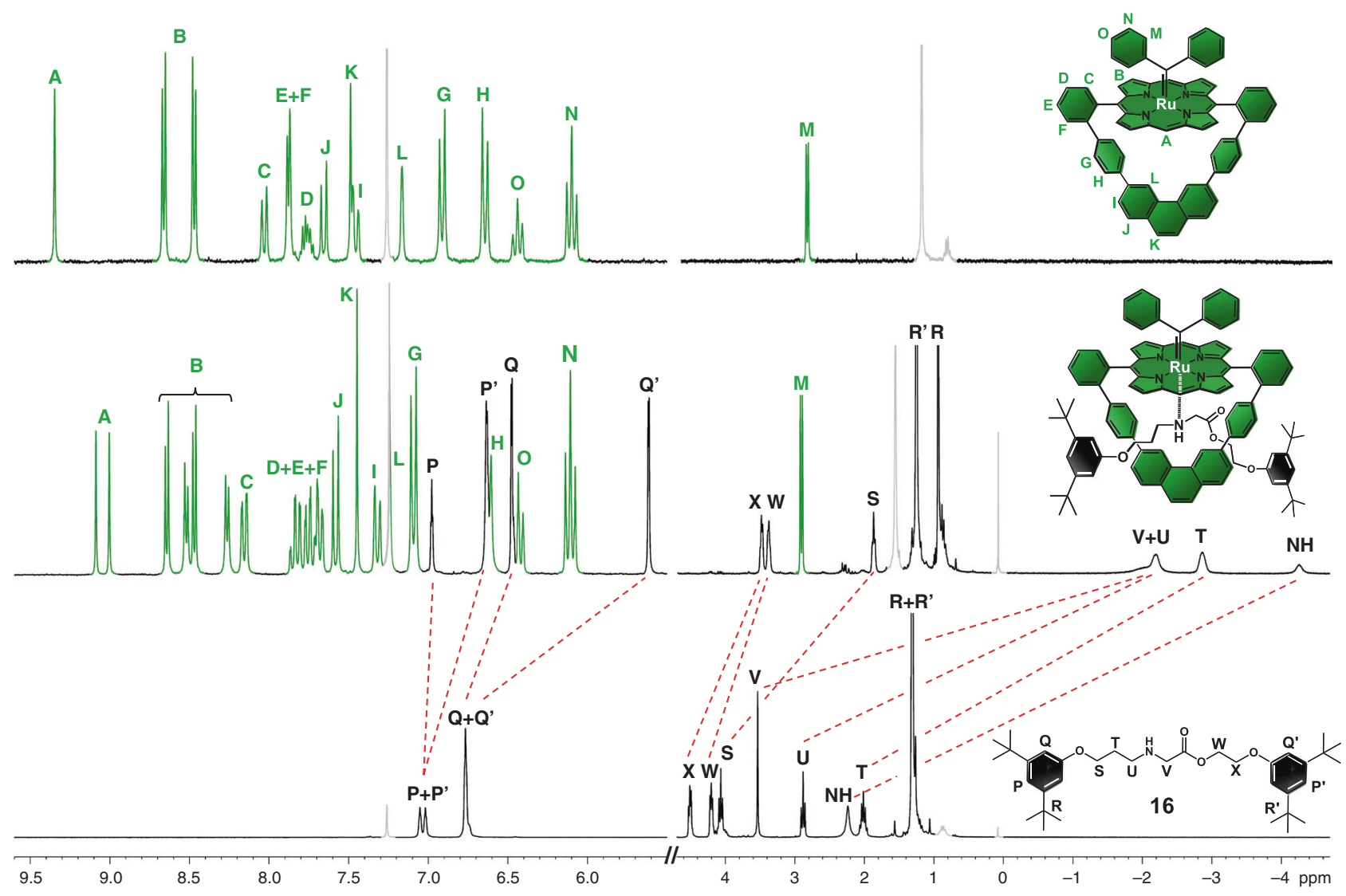

Fig. 5 Selected regions of the ${ }^{1} \mathbf{H}$ NMR spectra of macrocycle 11 (top), rotaxane 15 (middle) and thread 16 (bottom). Experimental conditions: $250 \mathrm{MHz}$, $\mathrm{CDCl}_{3}, 298 \mathrm{~K}$. Thread $\mathbf{1 6}$ was prepared aside for comparison purposes, using half-threads $\mathbf{1 3}$ and $\mathbf{1 4}$ as substrates and the acyclic version of $\mathbf{1 1}$ as promoter. Unambiguous proton assignments, including the $\mathrm{H}_{\mathrm{L}}$ signal in rotaxane $\mathbf{1 5}$ that overlaps with that of residual chloroform in the deuterated solvent, are based on 2D-NMR spectroscopy. Residual solvent peaks and aliphatic impurities are in gray: chloroform $(\delta=7.26$ ppm), water $(\delta=1.56$ ppm), "grease" $(\delta=$ $1.26 \mathrm{ppm}$ and $\delta=0.88 \mathrm{ppm})$ and silicone "grease" $(\delta=0.07 \mathrm{ppm})^{52}$.

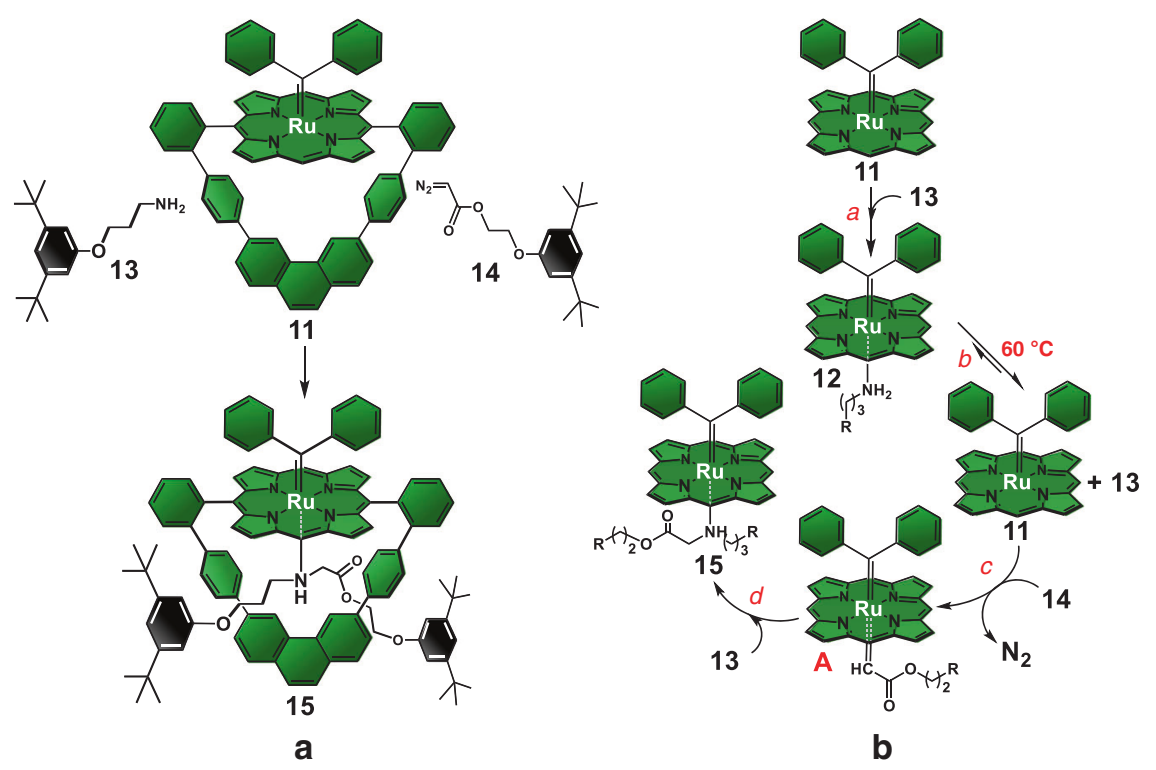

Fig. 6 Operation of the nanoreactor. a Synthesis of asymmetrical [2]rotaxanes by the active-metal template technique based on the Ru(II)porphyrinatepromoted $\mathrm{N}-\mathrm{H}$ carbene insertion reactions. Experimental conditions: benzene, $8 \mathrm{~h}, \mathrm{~N}_{2}$ atmosphere, quantitative yield relative to 11. b Conceivable reaction mechanism for the carbenoid N-H insertion process promoted by the Ru(II)porphyrinate subunit in $\mathbf{1 1}$ that quantitatively yield asymmetrical [2] rotaxane $\mathbf{1 5}$ through the active-metal template technique. The aromatic loop in $\mathbf{1 1}$ is not shown in the mechanism for clarity purposes. $\mathrm{R}=3,5$-di-tert-butylphenoxy stopper groups. 
noninterlocked threads (from reactions occurring exo-to the macrocycle's cavity) or rotaxane by-products (from intercomponent reactions) ${ }^{32}$ are observed in our experiments. Those findings are surprising and convincingly demonstrate that macrocycle $\mathbf{1 1}$ shows chemical selectivity towards promoting a single $\mathrm{N}-\mathrm{H}$ insertion. Most importantly, the single insertions occur exclusively through the macrocycle's cavity. Hence, macrocycle $\mathbf{1 1}$ is an exceptional endotopic catalyst.

For comparison purposes, we performed the $\mathrm{N}-\mathrm{H}$ carbene insertion reaction using as promoter the 5,15-bis(phenyl) $\mathrm{Ru}(\mathrm{II})$ porphyrinate with the diphenylcarbene axial ligand, which functions as the acyclic version of macrocycle 11, and 13 and 14 as substrates. Under the exact same conditions as those of the rotaxane assembly process, the acyclic $\mathrm{Ru}(\mathrm{II})$ porphyrinate leads to total consumption of $\mathbf{1 4}$ to afford a small amount of the respective dimer thread along with a mixture composed of the expected thread 16 (26\% isolated yield relative to 14; for structure of 16 see Fig. 5, bottom) and the tertiary amine counterpart (65\% isolated yield relative to 14; for structure see Supplementary Fig. S27), which is formed from the second carbenoid insertion into the secondary amine group of thread 16. Those findings unequivocally demonstrate that $\mathbf{1 1}$ functions as a molecular nanoreactor ${ }^{33}$ as the selectivity towards single $\mathrm{N}-\mathrm{H}$ carbenoid insertions is unachievable in bulk solution under the conditions investigated.

A complete spectroscopic characterization of the structure of rotaxane 15 by 2D-NMR (see Supplementary Figs. S81-S87) allows unambiguous assignment of all resonances, which along with MALDI-TOF mass spectrometry (Supplementary Fig. S9) provide unequivocal evidence for the proposed interlocked architecture for $\mathbf{1 5}$ shown in Fig. 6a. Furthermore, the unique structural features of the interlocked architecture of 15, revealed by the NMR investigation, provide valuable insights into the nature of the highly chemical selectivity observed in the rotaxane assembly process (vide infra).

In the ${ }^{1} \mathrm{H}$ NMR spectrum of 15 (Fig. 5, middle), one observes the duplication of the resonances of the meso-nuclei $\left(\mathrm{H}_{\mathrm{A}}\right)$ and the pyrrolic protons $\left(\mathrm{H}_{\mathrm{B}}\right)$ when compared to that of macrocycle 11, which is consistent with an asymmetrical [2] rotaxane architecture. The axial coordination of diphenylcarbene ligand is warranted by the observation of the diagnostic shielding of the resonances of protons $\mathrm{H}_{\mathrm{M}-\mathrm{O}}$ as well as by the characteristic strongly de-shielded carbene nuclei resonance at $\delta=330.3 \mathrm{ppm}$ in the ${ }^{13} \mathrm{C} \mathrm{NMR}$ spectrum of 15 (Supplementary Fig. S10) ${ }^{34-42}$. Two dimensional NOESY NMR analysis (Supplementary Fig. S11) reveals NOEs between protons $\mathrm{H}_{\mathrm{Q}}, \mathrm{H}_{\mathrm{S}}, \mathrm{H}_{\mathrm{T}}, \mathrm{H}_{\mathrm{U}} \mathrm{H}_{\mathrm{V}}$ and $\mathrm{NH}$ on the thread component and $\mathrm{H}_{\mathrm{G}}, \mathrm{H}_{\mathrm{H}}, \mathrm{H}_{\mathrm{L}}$ and $\mathrm{H}_{\mathrm{B}}$ on the macrocycle, thus confirming the formation of the mechanical bond in $\mathbf{1 5}$.

Resonances associated with the thread component (Fig. 5, bottom) informs about the structural peculiarities of rotaxane 15 . The secondary $\mathrm{N}-\mathrm{H}$ moiety is drastically shielded $(\Delta \delta=6.49$ ppm) in rotaxane $\mathbf{1 5}$ when compared to noninterlocked thread 16, revealing the coordination of the nitrogen atom of the secondary amine group on the thread to the $\mathrm{Ru}(\mathrm{II})$ ion on the macrocycle. As a result of such intercomponent chemical interaction, all nuclei on the thread $\left(\mathrm{H}_{\mathrm{S}-\mathrm{X}}\right)$, including those on the stoppers $\left(\mathrm{H}_{\mathrm{P}-\mathrm{R}}\right)$, are also shielded, indicating that the ring virtually covers the whole thread component in rotaxane $\mathbf{1 5}$.

The intercomponent interaction is inert at room temperature and, remarkably, at $333 \mathrm{~K}\left(60^{\circ} \mathrm{C}\right)$ as revealed by the variable temperature-NMR analysis of $\mathbf{1 5}$ (Supplementary Fig. S12), which is unusual for this type of coordinative bond ${ }^{40,41}$. The $\mathrm{R}_{1} \mathrm{R}_{2} \mathrm{HN}-\mathrm{Ru}$ axial interaction in $\mathbf{1 5}$ is kinetically stabilized by the mechanical bond, which constantly keeps the secondary $\mathrm{NH}$ binding group on the thread close to the $\mathrm{Ru}(\mathrm{II})$ ion on the macrocycle.
To generalize our method, macrocycle 11 was also investigated as promoter for S-H carbene insertions (Supplementary Fig. S13). By mixing thiol half-thread 17 (10 equiv) with macrocycle 11 (1 equiv) followed by one portion addition of half-thread 14 (10 equiv) in benzene at room temperature yields rotaxane 19 (Supplementary Fig. S13) in quantitative yield after 4 hours with complete recovering of the excess of substrates 14 and 17 as starting materials after workup. No signs of by-products were observed in the assembly process of $\mathbf{1 9}$ as in the case of the parent rotaxane 15. Most importantly, quantitative formation of rotaxane 19 informs that the $\mathrm{S}-\mathrm{H}$ carbene insertion occurs at room temperature rather than at $60^{\circ} \mathrm{C}$ as necessary for the $\mathrm{N}-\mathrm{H}$ insertion reaction. A complete structural characterization of rotaxane 19 by 2D-NMR spectroscopy (see Supplementary Figs. S15-S22) allows unambiguous assignment of all resonances and informs that the structural features of rotaxane 19 are very similar to that observed for rotaxane $\mathbf{1 5}$ analog. MALDI-TOF mass spectrometry (Supplementary Fig. S23) confirms the interlocked architecture for $\mathbf{1 9}$ by revealing the correct ion mass peak at 1624.446 (calculated for $\mathrm{C}_{106} \mathrm{H}_{98} \mathrm{~N}_{4} \mathrm{O}_{4} \mathrm{SRu}$ ) along with the characteristic fragmentation pattern expected for that type of rotaxanes $24,25,52$.

\section{Discussion}

The endotopic and chemical selectivity observed for 11 under the demanding conditions investigated for the $\mathrm{N}-\mathrm{H}$ carbene insertions in the rotaxane synthesis along with its distinct reaction outcome when compared to that afforded by the acyclic $\mathrm{Ru}(\mathrm{II})$ porphyrinate can be explained by three main factors, which are summarized in the proposed reaction mechanism depicted in Fig. 6b. Firstly, the lack of non-interlocked threads in the crude mixture, being them formed from carbene dimerization and/or mono/double $\mathrm{N}-\mathrm{H}$ insertions is warranted by the inert and stable diphenylcarbene axial ligand coordinated exo-to the macrocycle's cavity in 11. Such stability towards potential nucleophilic attack by the amine moiety in $\mathbf{1 3}$ and inertness towards ligand dissociation of the diphenylcarbene axial ligand are due to the significant electronic $\pi$-back donation from the $\mathrm{Ru}(\mathrm{II})$ ion to the carbene carbon as revealed by the short $\mathrm{Ru}-\mathrm{C}$ bond (1.852(4) $\AA$ ) measured in the crystal structure of $\mathbf{1 1}$ (Fig. 4) and verified in solution by NMR spectroscopy. Accordingly, only the internal axial position of $\mathbf{1 1}$ is available for activation of the substrates.

Secondly, coordination of the amino group in $\mathbf{1 3}$ to the internal axial position of 11 yields complex 12 (step $a$, Fig. 6b) prior to the initiation of the organometallic cycle. Formation of complex 12, which is inert at room temperature, informs about the preassociation of 11 and 13. Heating the reaction solution at $60^{\circ} \mathrm{C}$ renders complex 12 labile (step $b$, Fig. 6b), which means that halfthread 13 enters and leaves the coordination sphere of the $\mathrm{Ru}(\mathrm{II})$ ions 11 rapidly. Therefore, half-thread $\mathbf{1 3}$ is held nearby the Ru (II) ion during the rotaxane assembly process. As soon as the $\alpha$-estercarbenoid intermediate $\mathbf{A}$ is formed ${ }^{34-42}$ from the reaction between half-thread 14 and 11 after $\mathrm{N}_{2}$ extrusion (step $c$, Fig. 6b), the relatively stronger nucleophilic power of the amino group in 13 associated with its enforced local concentration near the cavity kinetically favor the $\mathrm{N}-\mathrm{H}$ insertion (step $d$, Fig. 6b) instead of the deleterious carbene dimerization. Therefore, symmetrical rotaxanes from dimerizations are not observed in our experiments.

Finally, the kinetic stabilization of the axial $\mathrm{R}_{1} \mathrm{R}_{2} \mathrm{HN}-\mathrm{Ru}$ coordinative interaction by the mechanical bond in 15 , in conjunction with the somewhat short molecular linkage between the two stoppers, force the latter to be held in front of the faces of the macrocyclic component in the rotaxane architecture. The steric shielding of both macrocycle's faces by the two stoppers associated with the small cavity provided by the rigid aromatic 
backbone completely block the access of exogenous substrates to the $\mathrm{Ru}(\mathrm{II})$ ions after rotaxane formation. Accordingly, the synergy between such steric and electronic effects shuts down the $\mathrm{Ru}(\mathrm{II})$ ion activity in $\mathbf{1 5}$ and explain the selectivity of the process towards the single $\mathrm{N}-\mathrm{H}$ insertion, even in the presence of a large excess of half-thread 14 at $60^{\circ} \mathrm{C}$. Conversely, the experiment promoted by the acyclic $\mathrm{Ru}(\mathrm{II})$ porphyrinate demonstrates that after the first $\mathrm{N}-\mathrm{H}$ carbene insertion that afford thread 16, the resulting axial $\mathrm{R}_{1} \mathrm{R}_{2} \mathrm{HN}-\mathrm{Ru}$ interaction is labile due to the lack of the mechanical bond. Congruently, 16 dissociates from the acyclic $\mathrm{Ru}(\mathrm{II})$ porphyrinate to allow the turnover of the $\mathrm{Ru}(\mathrm{II})$ ions, which then further react with additional 14 molecules present in excess in the reaction medium to generate the $\alpha$ estercarbenoid intermediate. The lack of the steric shielding in the acyclic $\mathrm{Ru}(\mathrm{II})$ porphyrinate permits the secondary amine group on 16 to attack the carbene intermediate to mostly afford the double inserted product.

The similar reaction outcome of the $\mathrm{S}-\mathrm{H}$ insertion when compared to that of the $\mathrm{N}-\mathrm{H}$ counterpart suggests that the former reaction should take place through the same mechanism proposed in Fig. 6b. In other words, coordination of the thiol group in $\mathbf{1 7}$ to the internal axial position of the $\mathrm{Ru}(\mathrm{II})$ ion in $\mathbf{1 1}$ should occur to form the hexacoordinated intermediate complex 18 (Supplementary Figure S13). However, the RHS-Ru interaction is labile at room temperature, and complex $\mathbf{1 8}$ does not require heating to generate carbenes from half-thread 14 as in the case of the parent complex 12 (Fig. 3).

In conclusion, a rigid porphyrin-based hollow receptor with a relatively small and well-defined central cavity revealed unusual coordinative properties as ligand for $\mathrm{Ru}(\mathrm{II})$ ions. Capitalizing on that, we developed a macrocyclic $\mathrm{Ru}(\mathrm{II})$ porphyrinate receptor bearing a stable and inert diphenylcarbene axial ligand, which functions as a nanoreactor and alters the outcome of $\mathrm{N}-\mathrm{H}$ bond carbene insertions when compared to that of its acyclic analog. The findings reported herein establish the basis for the synergetic combination between the steric properties of porphyrinate molecular capsules and formation of mechanical bonds as principles for the design of nanoreactors in order to gain control over the product distribution of challenging chemical transformations. The synthetic utility of the present methodology relies on the conversion of the substrates into mechanical bonds with quantitative efficiency via either $\mathrm{N}-\mathrm{H}$ or S-H carbene insertions even in the presence of substrate excess. As formation of the mechanical bond blocks the turnover of the $\mathrm{Ru}(\mathrm{II})$ ions through a combination of steric and electronic effects, each $\mathrm{Ru}(\mathrm{II})$ porphyrinate promotes one single carbene insertion, thus no intercomponent nor side-reactions are observed. The opportunity now exists to apply the technique described herein to assemble interlocked polymers with well-defined structures and low polydispersities. Increasingly, we can look forward to the preparation of copolyrotaxanes as we can now use the reaction temperature to selectively control the carbene insertions either in the S-H or N-H bonds. Such interlocked polymers and copolymers will allow a fundamental investigation of the effects of the inherent dynamic processes of mechanical bonds $s^{52}$ in the properties of macromolecules. Research along those lines is in progress.

\section{Methods}

Synthesis of macrocycle 11. In a $100 \mathrm{~mL}$ Schlenk flask, macrocycle $\mathbf{8}(0.010 \mathrm{~g}$, $0.011 \mathrm{mmol}, 1$ equiv) was dissolved in $20 \mathrm{~mL}$ of dichloromethane under magnetic stirring at room temperature and inert atmosphere. A dichloromethane solution of freshly prepared diphenyldiazomethane $(0.008 \mathrm{~g}, 0.040 \mathrm{mmol}$, in $4.00 \mathrm{~mL}$ of dichloromethane) was added dropwise to the solution of 8 over $3 \mathrm{~h}$. At the end of the addition, the reaction mixture was magnetically stirred for another $1 \mathrm{~h}$ at room temperature. The solvent was removed under reduced pressure and the crude product was purified by chromatography column on neutral alumina using a mixture of petroleum ether/dichloromethane $(1: 1, \mathrm{v} / \mathrm{v})$ as eluent to afford macrocycle 11 as a red solid in $64 \%$ yield $\left(7.4 \mathrm{mg}\right.$ ). TLC (petroleum ether: $\mathrm{CH}_{2} \mathrm{Cl}_{2}$, $1: 1 \mathrm{v} / \mathrm{v}): \mathrm{Rf}=0.56 . ;{ }^{1} \mathrm{H}$ NMR $\left(400 \mathrm{MHz}, \mathrm{CDCl}_{3}\right): \delta 9.34\left(\mathrm{~s}, 2 \mathrm{H}, \mathrm{H}_{\mathrm{A}}\right) ; 8.66(\mathrm{~d}, J=$ $\left.4.74 \mathrm{~Hz}, 4 \mathrm{H}, \mathrm{H}_{\mathrm{B}}\right) ; 8.47\left(\mathrm{~d}, J=4.70 \mathrm{~Hz}, 4 \mathrm{H}, \mathrm{H}_{\mathrm{B}}\right) ; 8.0 \overline{3}\left(\mathrm{~d}, J=7.36 \mathrm{~Hz}, 2 \mathrm{H}, \mathrm{H}_{\mathrm{C}}\right) ; 7.90$ $7.85\left(\mathrm{~m}, 4 \mathrm{H}, \mathrm{H}_{\mathrm{E}}\right.$ and $\left.\mathrm{H}_{\mathrm{F}}\right) ; 7.79-7.73\left(\mathrm{~m}, 2 \mathrm{H}, \mathrm{H}_{\mathrm{D}}\right) ; 7.65\left(\mathrm{~d}, J=8.20 \mathrm{~Hz}, 2 \mathrm{H}, \mathrm{H}_{\mathrm{J}}\right) ; 7.49$ $\left(\mathrm{s}, 2 \mathrm{H}, \mathrm{H}_{\mathrm{K}}\right) ; 7.46\left(\mathrm{~d}, \mathrm{~J}=8.39 \mathrm{~Hz}, 2 \mathrm{H}, \mathrm{H}_{\mathrm{I}}\right) ; 7.17\left(\mathrm{~s}, 2 \mathrm{H}, \mathrm{H}_{\mathrm{L}}\right) ; 6.91(\mathrm{~d}, \mathrm{~J}=8.17 \mathrm{~Hz}, 4 \mathrm{H}$, $\left.\mathrm{H}_{\mathrm{G}}\right) ; 6.65\left(\mathrm{~d}, J=8.17 \mathrm{~Hz}, 4 \mathrm{H}, \mathrm{H}_{\mathrm{H}}\right) ; 6.44\left(\mathrm{t}, J=7.30 \mathrm{~Hz}, 2 \mathrm{H}, \mathrm{H}_{\mathrm{O}}\right) ; 6.10(\mathrm{t}, J=$ $\left.7.56 \mathrm{~Hz}, 4 \mathrm{H}, \mathrm{H}_{\mathrm{N}}\right) ; 2.88\left(\mathrm{~d}, J=7.56 \mathrm{~Hz}, 4 \mathrm{H}, \mathrm{H}_{\mathrm{M}}\right)$. Impurities: 5.30 (dichloromethane); 1.26 and 0.88 (aliphatic impurities); ${ }^{13} \mathrm{C} \mathrm{NMR}\left(60 \mathrm{MHz}, \mathrm{CDCl}_{3}\right)$ : Macrocycle 11 was too insoluble to record ${ }^{13} \mathrm{C}$ NMR. MALDI-TOF $(\mathrm{m} / \mathrm{z}):[\mathrm{M}]^{+}$ calcd. for $\mathrm{C}_{71} \mathrm{H}_{44} \mathrm{~N}_{4} \mathrm{Ru}, 1054.260$; found 1054.191. UV-Vis $\left(\mathrm{CH}_{2} \mathrm{Cl}_{2}\right), 10^{-5} \mathrm{~mol} / \mathrm{L}$, $\lambda_{\max }(\mathrm{nm}): 274,317,391,424,527$ and 550 .

Synthesis of rotaxane 15. In a $10 \mathrm{~mL}$ Schlenk flask, macrocycle 11 (10 mg, 9.4 $\mu \mathrm{mol}, 1.0$ equiv) and half-thread $13(24.7 \mathrm{mg}, 94.0 \mu \mathrm{mol}, 10.0$ equiv) were dissolved in $1.2 \mathrm{~mL}$ of benzene under inert atmosphere at room temperature. The resulting solution was stirred for 15 minutes at room temperature. Compound $\mathbf{1 4}(29.9 \mathrm{mg}$, $94.0 \mu \mathrm{mol}, 10.0$ equiv) was added in one portion as a solid to the reaction flask and the mixture was heated at $60^{\circ} \mathrm{C}$ for 8 hours. The crude mixture was evaporated to dryness under reduced pressure. The viscous crude product was dissolved in a minimum amount of petroleum ether. The excess of half-thread $\mathbf{1 4}$ was insoluble in the petroleum ether phase and was removed using a pipette as a colorless oil. The petroleum-ether solution was further purified by preparative TLC on silica using petroleum ether/dichloromethane $(1: 1, \mathrm{v} / \mathrm{v})$ as eluent to afford the target rotaxane $\mathbf{1 5}$ as a red solid in quantitative yield relative to $11(15.0 \mathrm{mg})$ as the first fraction. The excess of half-thread 13 was isolated as the second fraction as a colorless oil. TLC (petroleum ether: $\left.\mathrm{CH}_{2} \mathrm{Cl}_{2}, 1: 1 \mathrm{v} / \mathrm{v}\right): \mathrm{Rf}=0.79 .{ }^{1} \mathrm{H}$ NMR $(250$ $\left.\mathrm{MHz}, \mathrm{CDCl}_{3}\right): \delta 9.09\left(\mathrm{~s}, 1 \mathrm{H}, \mathrm{H}_{\mathrm{A}}\right) ; 9.00\left(\mathrm{~s}, 1 \mathrm{H}, \mathrm{H}_{\mathrm{A}}\right) ; 8.64\left(\mathrm{~d}, J=4.83 \mathrm{~Hz}, 2 \mathrm{H}, \mathrm{H}_{\mathrm{B}}\right)$; $8.52\left(\mathrm{~d}, J=4.5 \overline{9} \mathrm{~Hz}, 2 \mathrm{H}, \mathrm{H}_{\mathrm{B}}\right) ; 8.47\left(\mathrm{~d}, J=4.83 \mathrm{~Hz}, 4 \mathrm{H}, \mathrm{H}_{\mathrm{B}}\right) ; 8.26(\mathrm{~d}, J=4.83 \mathrm{~Hz}$, $\left.4 \mathrm{H}, \mathrm{H}_{\mathrm{B}}\right) ; 8.16\left(\mathrm{~d}, J=7.49 \mathrm{~Hz}, \mathrm{H}_{\mathrm{C}}\right) ; 7.88-7.65\left(\mathrm{~m}, 6 \mathrm{H}, \mathrm{H}_{\mathrm{D}}, \mathrm{H}_{\mathrm{E}}\right.$ and $\left.\mathrm{H}_{\mathrm{F}}\right) ; 7.58(\mathrm{~d}, J=$ $\left.8.29 \mathrm{~Hz}, 2 \mathrm{H}, \mathrm{H}_{\mathrm{J}}\right) ; 7.44\left(\mathrm{~s}, 2 \mathrm{H}, \mathrm{H}_{\mathrm{K}}\right) ; 7.32\left(\mathrm{~d}, J=8.29,2 \mathrm{H}, \mathrm{H}_{\mathrm{I}}\right) ; 7.26\left(\mathrm{~s}, 2 \mathrm{H}, \mathrm{H}_{\mathrm{L}}\right) ; 7.09$ $\left(\mathrm{d}, J=8.29,4 \mathrm{H}, \mathrm{H}_{\mathrm{G}}\right) ; 6.98\left(\mathrm{t}, J=1.48 \mathrm{~Hz}, 1 \mathrm{H}, \mathrm{H}_{\mathrm{P}^{\prime}}\right) ; 6.66-6.58\left(\mathrm{~m}, 5 \mathrm{H}, \mathrm{H}_{\mathrm{P}}\right.$ and $\left.\mathrm{H}_{\mathrm{H}}\right)$; $6.47\left(\mathrm{~d}, J=1.43,2 \mathrm{H}, \mathrm{H}_{\mathrm{Q}^{\prime}}\right) ; 6.43\left(\mathrm{t}, J=7.36,2 \mathrm{H}, \mathrm{H}_{\mathrm{O}}\right) ; 6.10\left(\mathrm{t}, J=7.73,4 \mathrm{H}, \mathrm{H}_{\mathrm{N}}\right) ; 5.61$ $\left(\mathrm{d}, J=1.52 \mathrm{~Hz}, \mathrm{H}_{\mathrm{Q}}\right) ; 3.48\left(\mathrm{br}, 2 \mathrm{H}, \mathrm{H}_{\mathrm{X}}\right) ; 3.37\left(\mathrm{br}, 2 \mathrm{H}, \mathrm{H}_{\mathrm{W}}\right) ; 2.91(\mathrm{~d}, J=7.10,4 \mathrm{H}$, $\left.\mathrm{H}_{\mathrm{M}}\right) ; 1.87\left(\mathrm{t}, J=5.35 \mathrm{~Hz}, 2 \mathrm{H}, \mathrm{H}_{\mathrm{S}}\right) ; 1.25\left(\mathrm{~s}, 18 \mathrm{H}, \mathrm{H}_{\mathrm{R}}\right) ; 0.94\left(\mathrm{~s}, 18 \mathrm{H}, \mathrm{H}_{\mathrm{R}}\right) ;$ from -1.76 to $-2.45\left(\mathrm{br}, 4 \mathrm{H}, \mathrm{H}_{\mathrm{V}}\right.$ and $\left.\mathrm{H}_{\mathrm{U}}\right) ;-2.86\left(\mathrm{br}, 2 \mathrm{H}, \mathrm{H}_{\mathrm{T}}\right) ;-4.25(\mathrm{br}, 1 \mathrm{H}, \mathrm{NH})$. Impurities: 1.56 (residual water in the $\mathrm{CDCl}_{3}$ solvent); 0.07 (silicon "grease"). ${ }^{\top 3} \mathrm{C}$ NMR (60 $\left.\mathrm{MHz}, \mathrm{CDCl}_{3}\right): \delta 330.3 ; 168.2 ; 162.7 ; 158.0 ; 157.9 ; 152.2 ; 151.3 ; 144.6 ; 144.1 ; 143.9$; $143.4 ; 143.1 ; 141.3 ; 140.3 ; 140.0 ; 139.7 ; 134.9 ; 133.1 ; 132.8 ; 131.8 ; 131.6 ; 130.8$; $129.9 ; 129.6 ; 129.5 ; 128.1 ; 127.9 ; 126.2 ; 125.8 ; 125.2 ; 123.4 ; 123.1 ; 118.4 ; 115.2$; $113.9 ; 111.6 ; 108.8 ; 108.0 ; 107.4 ; 107.0 ; 64.7 ; 64.3 ; 62.4 ; 53.5 ; 46.1 ; 44.2 ; 35.0 ; 34.6$; $31.5 ; 31.3 ; 29.8 ; 22.8 ; 22.1 ; 14.2$. Impurities: 53.5 (residual dichloromethane); 29.8 ; 22.8 and 14.2 (aliphatic impurities). MALDI-TOF $(\mathrm{m} / \mathrm{z}):[\mathrm{M}]^{+}$calcd. for $\mathrm{C}_{106} \mathrm{H}_{99} \mathrm{~N}_{5} \mathrm{O}_{4} \mathrm{Ru}, 1607.6741$; found 1607.603. UV-Vis, $\lambda_{\max }(\mathrm{nm}): 270,313,398$, 425 and 530. FTIR (ATR), $v\left(\mathrm{~cm}^{-1}\right): 1741$.

Synthesis of rotaxane 19. In a $10 \mathrm{~mL}$ Schlenk flask, under inert atmosphere, macrocycle 11 (10 mg, $0.0094 \mathrm{mmol}, 1.0$ equiv) and half-thread 17 (26.0 mg, 0.094 mmol, 10.0 equiv) were dissolved in $1.2 \mathrm{~mL}$ of benzene at room temperature. The resulting solution was stirred for 15 minutes at rt. Compound $\mathbf{1 4}(29.9 \mathrm{mg}, 0,094$ mmol, 10.0 equiv) was added as a solid to the reaction flask and the mixture was magnetically stirred at room temperature for 4 hours. TLC analyses on silica revealed that macrocycle $\mathbf{1 1}$ was completely interlocked after that period. The crude mixture was evaporated to dryness under reduced pressure, dissolved in a minimum amount of petroleum ether and purified by preparative TLC on silica using petroleum ether/dichloromethane $(50: 50, \mathrm{v} / \mathrm{v})$ as eluent to afford the target rotaxane 19 as a red solid in quantitative yield ( $91 \%$ isolated yield; $0.014 \mathrm{mg}$ ) as the second fraction. The excess of half-threads $\mathbf{1 7}$ and $\mathbf{1 4}$ was completely recovered as the first (colorless oil) and third (yellowish oil) fractions, respectively. TLC (petroleum ether: $\left.\mathrm{CH}_{2} \mathrm{Cl}_{2}, 1: 1 \mathrm{v} / \mathrm{v}\right): \mathrm{Rf}=0.79 .{ }^{1} \mathrm{H}$ NMR $\left(500 \mathrm{MHz}_{2} \mathrm{CDCl}_{3}\right): \delta 9.16(\mathrm{~s}$, $\left.1 \mathrm{H}, \mathrm{H}_{\mathrm{A}}\right) ; 9.08\left(\mathrm{~s}, 1 \mathrm{H}, \mathrm{H}_{\mathrm{A}}\right) ; 8.63\left(\mathrm{~d}, J=4.55 \mathrm{~Hz}, 2 \mathrm{H}, \mathrm{H}_{\mathrm{B}}\right) ; 8.53(\mathrm{~d}, J=4.7 \overline{3} \mathrm{~Hz}, 2 \mathrm{H}$, $\left.\mathrm{H}_{\mathrm{B}}\right) ; 8.48\left(\mathrm{~d}, J=4.55 \mathrm{~Hz}, 4 \mathrm{H}, \mathrm{H}_{\mathrm{B}}\right) ; 8.36\left(\mathrm{~d}, J=4.77 \mathrm{~Hz}, 4 \mathrm{H}, \mathrm{H}_{\mathrm{B}}\right) ; 8.23(\mathrm{~d}, J=6.57$ $\left.\mathrm{Hz}, \mathrm{H}_{\mathrm{C}}\right) ; 7.84\left(\mathrm{td}, J=7.62 \mathrm{~Hz}\right.$ e $\left.1.01 \mathrm{~Hz}, 2 \mathrm{H} \mathrm{H}_{\mathrm{D}}\right) ; 7.75(\mathrm{td}, J=7.53 \mathrm{~Hz}$ e $1.28 \mathrm{~Hz}$ $\left.2 \mathrm{H}, \mathrm{H}_{\mathrm{E}}\right) ; 7.70\left(\mathrm{~d}, J=7.67,2 \mathrm{H}, \mathrm{H}_{\mathrm{F}}\right) ; 7.58\left(\mathrm{~d}, J=8.26 \mathrm{~Hz}, 2 \mathrm{H}, \mathrm{H}_{\mathrm{J}}\right) ; 7.44\left(\mathrm{~s}, 2 \mathrm{H}, \mathrm{H}_{\mathrm{K}}\right)$; $7.37\left(\mathrm{~s}, 2 \mathrm{H}, \mathrm{H}_{\mathrm{L}}\right) ; 7.33\left(\mathrm{~d}, J=8.35,2 \mathrm{H}, \mathrm{H}_{\mathrm{I}}\right) ; 7.03\left(\mathrm{~d}, J=8.26,4 \mathrm{H}, \mathrm{H}_{\mathrm{G}}\right) ; 6.94(\mathrm{br}, 1 \mathrm{H}$, $\left.\mathrm{H}_{\mathrm{P}}\right)$; $6.71\left(\mathrm{br}, 1 \mathrm{H}, \mathrm{H}_{\mathrm{P}}\right) ; 6.65\left(\mathrm{~d}, J=8.37 \mathrm{~Hz}, 4 \mathrm{H}, \mathrm{H}_{\mathrm{H}}\right) ; 6.49\left(\mathrm{t}, J=7.44,2 \mathrm{H}, \mathrm{H}_{\mathrm{O}}\right)$; $6.39\left(\mathrm{~s}, 2 \mathrm{H}, \mathrm{H}_{\mathrm{Q}^{\prime}}\right) ; 6.15\left(\mathrm{t}, J=7.79,4 \mathrm{H}, \mathrm{H}_{\mathrm{N}}\right) ; 5.85\left(\mathrm{~s}, 2 \mathrm{H}, \mathrm{H}_{\mathrm{Q}}\right) ; 3.18\left(\mathrm{br}, 2 \mathrm{H}, \mathrm{H}_{\mathrm{X}}\right)$; $2.99\left(\mathrm{~d}, J=7.25,4 \mathrm{H}, \mathrm{H}_{\mathrm{M}}\right) ; 2.73\left(\mathrm{br}, 2 \mathrm{H}, \mathrm{H}_{\mathrm{W}}\right) ; 2.38\left(\mathrm{br}, J=5.35 \mathrm{~Hz}, 2 \mathrm{H}, \mathrm{H}_{\mathrm{S}}\right) ; 1.23(\mathrm{~s}$, $\left.18 \mathrm{H}, \mathrm{H}_{\mathrm{R}}\right) ; 1.00\left(\mathrm{~s}, 18 \mathrm{H}, \mathrm{H}_{\mathrm{R}}\right) ;-1.76\left(\mathrm{br}, 2 \mathrm{H}, \mathrm{H}_{\mathrm{V}}\right) ;-1.90\left(\mathrm{br}, 2 \mathrm{H}, \mathrm{H}_{\mathrm{U}}\right) ;-2.05(\mathrm{~s}, 2 \mathrm{H}$, $\mathrm{H}_{\mathrm{T}}$ ). Impurities: 1.58 (residual water); 1.26 e 0.07 (aliphatic impurities). ${ }^{13} \mathrm{C}$ NMR $\left(60 \mathrm{MHz}, \mathrm{CDCl}_{3}\right): \delta 167.3 ; 161.4 ; 158.0 ; 157.7 ; 152.2 ; 151.7 ; 144.9 ; 144.5 ; 143.8$; $143.2 ; 143.1 ; 141.0 ; 140.2 ; 139.7 ; 139.4 ; 135.0 ; 133.0 ; 132.7 ; 131.9 ; 131.7 ; 130.8$; $130.1 ; 129.8 ; 129.7 ; 128.3 ; 128.2 ; 128.0 ; 126.2 ; 125.7 ; 125.4 ; 125.2 ; 123.9 ; 123.6$; $119.0 ; 115.2 ; 114.2 ; 112.6 ; 108.6 ; 108.1 ; 107.4 ; 107.0 ; 65.4 ; 64.4 ; 62.5 ; 35.0 ; 34.7 ; 31.5$; $31.3 ; 29.8 ; 28.6 ; 28.0 ; 23.7$. Impurities: $29.8 ; 22.8$ e 14.2 (aliphatic impurities). MALDI-TOF $(m / z)$ : $[\mathrm{M}]^{+}$calcd. for $\mathrm{C}_{106} \mathrm{H}_{98} \mathrm{~N}_{4} \mathrm{O}_{4} \mathrm{Ru}, 1624.635$; found 1624.446.

NMR experiments. ${ }^{1} \mathrm{H},{ }^{13} \mathrm{C},{ }^{31} \mathrm{P}, \mathrm{COSY}, \mathrm{HMBC}$ and HSQC NMR spectra were obtained on either a Bruker AVANCE $250(250 \mathrm{MHz})$ or a Bruker AVANCE 500 $(500 \mathrm{MHz})$, in all cases using deuterated solvents as the lock. The spectra were 
collected at $298 \mathrm{~K}$ or $333 \mathrm{~K}$, and chemical shifts reported in parts per million $(\delta, \mathrm{ppm})$ were referenced to residual solvent peak. Residual solvent peaks and eventual aliphatic impurities were assigned according to literature ${ }^{53}$. Two dimensional NOESY NMR spectra were acquired on a Bruker AVANCE $400(400 \mathrm{MHz})$ using $\mathrm{CDCl}_{3}$ as deuterated solvent at $298 \mathrm{~K}$ and $400 \mathrm{~ms}$ mixing time.

Single-crystal X-ray diffraction measurements. X-Ray quality crystals of macrocycles $\mathbf{7}$ and $\mathbf{1 1}$ were grown from slow evaporation of a dichloromethane/ methanol/tetrahydrofuran and dichloromethane/acetonitrile saturated solutions, respectively. Both compounds crystalized as red needle-like single crystals with approximate dimensions of $0.025 \mathrm{~mm} \times 0.01 \mathrm{~mm} \times 0.05 \mathrm{~mm}$ for macrocycle 7 and $0.27 \times 0.08 \times 0.08 \mathrm{~mm}$ for macrocycle 11. The X-ray diffraction experiments were performed at the MX2 beamline at the UVX synchrotron source at the Brazilian Synchrotron Light Source. For further information about the X-ray experiments, see Supplementary Material.

\section{Data availability}

All the data generated or analyzed during this study are included in this published article (and its supplementary information files) or available from the authors upon reasonable request. The $\mathrm{X}$-ray crystallographic coordinates for structures reported in this study have been deposited at the Cambridge Crystallographic Data Centre (CCDC), under deposition numbers 1883084 and 1988009. These data can be obtained free of charge from The Cambridge Crystallographic Data Centre via www.ccdc.cam.ac.uk/ data_request/cif.

Received: 8 April 2020; Accepted: 29 October 2020;

Published online: 11 December 2020

\section{References}

1. Rickhaus, M. et al. Global aromaticity at the nanoscale. Nat. Chem. 12, 236 (2020).

2. Megiatto, J. D. Jr. \& Schuster, D. I. Introduction of useful peripheral functional groups on [2]catenanes by combining $\mathrm{Cu}$ (I) template synthesis with "click" chemistry. N. J. Chem. 34, 276 (2010).

3. Zhao, J. et al. Proton mediated spin state transition of cobalt heme analogs. Nat. Commun. 10, 2303 (2019).

4. Megiatto, J. D. Jr., Spencer, R. \& Schuster, D. I. Optimizing reaction conditions for synthesis of electron donor-[60]fullerene interlocked multiring systems. J. Mat. Chem. 21, 1544 (2011).

5. Longevial, J.-F. et al. Peripherally metalated porphyrins with applications in catalysis, molecular electronics and biomedicine. Chem. Eur. J. 24, 15442 (2018).

6. Megiatto, J. D. Jr., Schuster, D. I., de Miguel, G., Wolfrum, S. \& Guldi, D. M. Topological and conformational effects on electron transfer dynamics in porphyrin-[60]Fullerene interlocked systems. Chem. Mat. 24, 2472 (2012).

7. Polizzi, N. F. et al. De novo design of a hyperstable non-natural protein-ligand complex with sub- ̊ accuracy. Nat. Chem. 9, 1157 (2017).

8. Antoniuk-Pablant, A. et al. A new method for the synthesis of $\beta$-cyano substituted porphyrins and their use as sensitizers in photoelectrochemical devices. Mat. Chem. A 4, 2976 (2016).

9. Zhang, W. et al. Porous metal-metalloporphyrin gel as catalytic binding pocket for highly efficient synergistic catalysis. Nat. Commun. 10, 1913 (2019).

10. Auwaerter, W., Ecija, D., Klappenberger, F. \& Barth, J. V. Porphyrins at interfaces. Nat. Chem. 7, 105 (2015).

11. Megiatto, J. D. Jr., Schuster, D. I., Abwandner, S., de Miguel, G. \& Guldi, D. M. J. Am. Chem. Soc. 132, 3847 (2010).

12. Ousaka, N. et al. Water-mediated deracemization of a bisporphyrin helicate assisted by diastereoselective encapsulation of chiral guests. Nat. Commun. 10, 1457 (2019).

13. Kirner, S. V., Henkel, C., Guldi, D. M., Megiatto, J. D. Jr. \& Schuster, D. I. Chem. Sci. 6, 7293 (2015).

14. Wang, S. et al. Controllable hierarchical self-assembly of porphyrin-derived supra-amphiphiles. Nat. Commun. 10, 1399 (2019).

15. Kirner, S. V., Guldi, D. M., Megiatto, J. D. Jr. \& Schuster, D. I. Synthesis and photophysical properties of new catenated electron donor-acceptor materials with magnesium and free base porphyrins as donors and C60 as the acceptor. Nanoscale 7, 1145 (2015).

16. Megiatto, J. D. Jr. et al. Intramolecular hydrogen bonding as a synthetic tool to induce chemical selectivity in acid catalyzed porphyrin synthesis. Chem. Comm. 48, 4558 (2012).

17. Megiatto, J. D. Jr. et al. A bioinspired redox relay that mimics radical interactions of the Tyr-His pairs of photosystem II. Nat. Chem. 6, 423 (2014).

18. Koepf, M., Wytko, J. A., Bucher, J.-P. \& Weiss, J. Surface-tuned assembly of porphyrin coordination oligomers. J. Am. Chem. Soc. 130, 9994 (2008).
19. Gunter, M. J. \& Mullen, K. M. Dynamic axial ligand-site exchange in facially discriminated ruthenium(II) carbonyl and rhodium(III) halide metalloporphyrins. Inorg. Chem. 46, 4876 (2007).

20. Koepf, M. et al. Design of porphyrin-based ligands for the assembly of [dblock metal: calcium] bimetallic centers. Dalton Trans. 46, 4199-4208 (2017)

21. Urbani, M. \& Torres, T. Tautomerism and atropisomerism in free-base (meso)-strapped porphyrins: static and dynamic aspects. Chem. Eur. J. 20, 16337 (2014).

22. Tang, H. \& Dolphin, D. Interaction of derivatized capped iron(II) porphyrin complexes with CO and O2. Inorg. Chem. 35, 6539 (1996).

23. Collman, J.-P., Lee, V. J., Zhang, X., Ibers, J. A. \& Brauman, J. I. Enantioselective epoxidation of unfunctionalized olefins catalyzed by threitolstrapped manganese porphyrins. J. Am. Chem. Soc. 115, 3834 (1993).

24. Alcântara, A. F. P. et al. Olefin cyclopropanation by radical carbene transfer reactions promoted by cobalt (II)/porphyrinates: active-metal-template synthesis of [2]rotaxanes. Angew. Chem. Int. Ed. 57, 8979 (2018).

25. Alcântara, A. F. P. et al. Control over the redox cooperative mechanism of radical carbene transfer reactions for the efficient active-metal-template synthesis of [2]rotaxanes. Chem. Eur. J. 26, 7808 (2020).

26. Wolf, M. et al. Light triggers molecular shuttling in rotaxanes: control over proximity and charge recombination. Chem. Sci. 10, 3846 (2019).

27. Miyazaki, Y. et al. CuAAC in a distal pocket: metal active-template synthesis of strapped-porphyrin [2] rotaxanes. Chem. Eur. J. 23, 13579 (2017).

28. Lang, H. Y. et al. Next-generation D2-symmetric chiral porphyrins for cobalt (II)-based metalloradical catalysis: catalyst engineering by distal bridging. Angew. Chem. Int. Ed. 58, 2670 (2019).

29. Lang, K., Torker, S., Wojtas, L. \& Zhang, X. P. Asymmetric induction and enantiodivergence in catalytic radical $\mathrm{C}-\mathrm{H}$ amination via enantiodifferentiative $\mathrm{H}$-atom abstraction and stereoretentive radical substitution. J. Am. Chem. Soc. 141, 12388 (2019).

30. Thordarson, P., Bijsterveld, E. J. A., Rowan, A. E. \& Nolte, R. J. M. Epoxidation of polybutadiene by a topologically linked catalyst. Nature 424 915 (2003).

31. van Dongen, S. F. M. et al. A clamp-like biohybrid catalyst for DNA oxidation. Nat. Chem. 5, 945 (2013).

32. van den Boomen, O. I. et al. Carbenoid transfer reactions catalyzed by a ruthenium porphyrin macrocycle. Tetrahedron 73, 5029 (2017).

33. Petrosko, S. H., Johnson, R., White, H. \& Mirkin, C. A. Nanoreactors: small spaces, big implications in chemistry. J. Am. Chem. Soc. 138, 7443 (2016).

34. Zhou, C.-Y., Huang, J.-S. \& Che, C.-M. Ruthenium-porphyrin-catalyzed carbenoid transfer reactions. Synlett 18, 2681 (2010).

35. Che, C.-M. et al. Asymmetric inter- and intramolecular cyclopropanation of alkenes catalyzed by chiral ruthenium porphyrins. synthesis and crystal structure of a chiral metalloporphyrin carbene complex. J. Am. Chem. Soc. 123, 4119 (2001)

36. Ho, C.-M. et al. A water-soluble ruthenium glycosylated porphyrin catalyst for carbenoid transfer reactions in aqueous media with applications in bioconjugation reactions. J. Am. Chem. Soc. 132, 1886 (2010).

37. Reddy, A. R., Zhou, C.-Y., Guo, Z., Wei, J. \& Che, C.-M. Ruthenium-porphyrin-catalyzed diastereoselective intramolecular alkyl carbene insertion into $\mathrm{C}-\mathrm{H}$ bonds of alkyl diazomethanes generated in situ from N-tosylhydrazones. Angew. Chem. Int. Ed. 53, 14175 (2014).

38. Li, Y. et al. Spectral, structural, and electrochemical properties of ruthenium porphyrin diaryl and aryl(alkoxycarbonyl) carbene complexes: influence of carbene substituents, porphyrin substituents, and trans-axial ligands. Chem. Eur. J. 10, 3486 (2004).

39. Yu, X.-Q., Huang, J. S., Yu, W.-Y. \& Che, C.-M. Polymer-supported ruthenium porphyrins: versatile and robust epoxidation catalysts with unusual selectivity. J. Am. Chem. Soc. 122, 5337 (2000).

40. Galardon, E., Le Maux, P. \& Simonneaux, G. Cyclopropanation of alkenes, $\mathrm{N}-\mathrm{H}$ and $\mathrm{S}-\mathrm{H}$ insertion of ethyl diazoacetate catalysed by ruthenium porphyrin complexes. Tetrahedron 56, 615 (2000).

41. Galardon, E., Roué, S., Le Maux, P. \& Simonneaux, G. Asymmetric cyclopropanation of alkenes and diazocarbonyl insertion into S-H bonds catalyzed by a chiral porphyrin Ru (II) complex. Tetrahedron Lett. 39, 2333 (1998).

42. Chan, K.-H., Guan, X., Lo, V. K.-Y. \& Che, C.-M. Elevated catalytic activity of ruthenium (II)-porphyrin-catalyzed carbene/nitrene transfer and insertion reactions with N-heterocyclic carbene ligands. Angew. Chem. Int. Ed. 53, 2982 (2014).

43. Dirks, J. W., Underwood, G., Matheson, J. C. \& Gust, D. Conformational dynamics of alpha.,. beta.,. gamma.,. delta-tetraarylporphyrins and their dications. J. Org. Chem. 44, 2551 (1979).

44. Stulz, E. et al. Phosphine and phosphonite complexes of a ruthenium (II) porphyrin. 1. Synthesis, structure, and solution state studies. Inorg. Chem. 41, 5255 (2002)

45. Sovocool, G. W., Hopf, F. R. \& Whitten, D. G. Metalloporphyrin photochemistry. Ruthenium(II) porphyrin photodimer with a metal-metal bond. J. Am. Chem. Soc. 94, 4350 (1972). 
46. Spiccia, L., Deacon, G. B. \& Kepert, C. M. Synthetic routes to homoleptic and heteroleptic ruthenium(II) complexes incorporating bidentate imine ligands. Coord. Chem. Rev. 248, 1329 (2004).

47. Samojłowicz, C., Bieniek, M. \& Grela, K. Ruthenium-based olefin metathesis catalysts bearing N-heterocyclic carbene ligands. Chem. Rev. 109, 3708 (2009).

48. Frémont, P., Marion, N. \& Nolan, S. P. Carbenes: synthesis, properties, and organometallic chemistry. Coord. Chem. Rev. 253, 862 (2009).

49. Lee, M.-T. \& Hu, C.-H. Density functional study of N-heterocyclic and diamino carbene complexes: comparison with phosphines. Organometallics 23, 976 (2004).

50. Beves, J. E., Blight, B. A., Campbell, C. J., Leigh, D. A. \& McBurney, R. T. Strategies and tactics for the metal-directed synthesis of rotaxanes, knots, catenanes, and higher order links. Angew. Chem. Int. Ed. 50, 9260 (2011).

51. Denis, M. \& Goldup, S. M. The active metal template approach to interlocked molecules. Nat. Rev. 1, 1 (2017).

52. Megiatto, J. D. Jr., Schuster, D. I. \& Guldi, D. M. Design, synthesis and photoinduced processes in molecular interlocked photosynthetic [60]fullerene systems. Chem. Soc. Rev. 49, 8 (2020).

53. Gottlieb, H. E., Kotlyar, V. \& Nudelman, A. NMR chemical shifts of common laboratory solvents as trace impurities. J. Org. Chem. 62, 7512 (1997).

\section{Acknowledgements}

The authors are grateful to the Fundação de Amparo à Pesquisa do Estado de São Paulo (FAPESP) for financial support (Grants 2013/22160-0 and 2015/23761-2) and fellowship for LAF (2017/06752-5). JDMJ thanks Conselho Nacional de Desenvolvimento Científico e Tecnológico (CNPq) for the research fellowship (\#307635/2018-0). We also thank Prof. Anita J. Marsaioli for the MALDI-TOF mass spectrometer and the Brazilian Synchrotron Light Laboratory (LNLS), an open national facility operated by the Brazilian Centre for Research in Energy and Materials (CNPEM) for the Brazilian Ministry for Science, Technology, Innovations and Communications (MCTIC). MAR thanks the suport from Fundação de Amparo à Pesquisa do Espírito Santo (FAPES) Grant \#174/2019.

\section{Author contributions}

J.D.M.J. conceived, designed the experiments, directed the research, analyzed/interpreted the data and compose the manuscript. L.A.F. performed the experiments, analyzed/ interpreted the data and contributed to the manuscript preparation. M.P.A., A.F.P.A. and V.H.R. provided some help with the syntheses. L.A.F., M.A.R. and W.P.B. are responsible for the crystal structures. All authors discussed and commented on the manuscript.

\section{Competing interests}

The authors declare no competing interests.

\section{Additional information}

Supplementary information is available for this paper at https://doi.org/10.1038/s41467 020-20046-x.

Correspondence and requests for materials should be addressed to J.D.M.Jr.

Peer review information Nature Communications thanks the anonymous reviewer(s) for their contribution to the peer review of this work.

Reprints and permission information is available at http://www.nature.com/reprints

Publisher's note Springer Nature remains neutral with regard to jurisdictional claims in published maps and institutional affiliations.

Open Access This article is licensed under a Creative Commons Attribution 4.0 International License, which permits use, sharing, adaptation, distribution and reproduction in any medium or format, as long as you give appropriate credit to the original author(s) and the source, provide a link to the Creative Commons license, and indicate if changes were made. The images or other third party material in this article are included in the article's Creative Commons license, unless indicated otherwise in a credit line to the material. If material is not included in the article's Creative Commons license and your intended use is not permitted by statutory regulation or exceeds the permitted use, you will need to obtain permission directly from the copyright holder. To view a copy of this license, visit http://creativecommons.org/ licenses/by/4.0/.

(C) The Author(s) 2020 